\title{
An overview of chemical oxidation-based remediation technologies for non-aqueous phase liquids removal from soil
}

\author{
Alazaiza M.Y.D. ${ }^{1 *}$, Albahnasawi A. ${ }^{2}$, Copty N.K. ${ }^{3}$, Ali G.A.M. ${ }^{4}$, Bashir M.J.K. ${ }^{5}$, Abu Amr S.S. ${ }^{6}$, Abushammala M.F.M. ${ }^{7}$, Nassani D.E. ${ }^{8}$ and \\ Al Maskari T. ${ }^{1}$ \\ ${ }^{1}$ Department of Civil and Environmental Engineering, College of Engineering, A'Sharqiyah University, 400, Ibra, Oman \\ ${ }^{2}$ Gebze Technical University, Department of Environmental Engineering-Water Center (SUMER), 41400 Kocaeli, Turkey \\ ${ }^{3}$ Institute of Environmental Sciences, Bogazici University, Bebek, Istanbul, Turkey \\ ${ }^{4}$ Chemistry Department, Faculty of Science, Al-Azhar University, 71524, Assiut, Egypt \\ ${ }^{5}$ Department of Environmental Engineering, Faculty of Engineering and Green Technology (FEGT), Universiti Tunku Abdul Rahman, \\ 31900, Kampar, Perak, Malaysia \\ ${ }^{6}$ Faculty of Engineering, Karabuk University, Demir Campus, 78050, Karabuk, Turkey \\ ${ }^{7}$ Department of Civil Engineering, Middle East College, Knowledge Oasis Muscat, PB No 79, Oman \\ ${ }^{8}$ Department of Civil Engineering, Hasan Kalyoncu University, 27500 Gaziantep, Turkey \\ Received: 21/08/2021, Accepted: 09/11/2021, Available online: 17/01/2022 \\ *to whom all correspondence should be addressed: e-mail: my.azaiza@gmail.com \\ https://doi.org/10.30955/gnj.003909
}

\section{Graphical abstract}

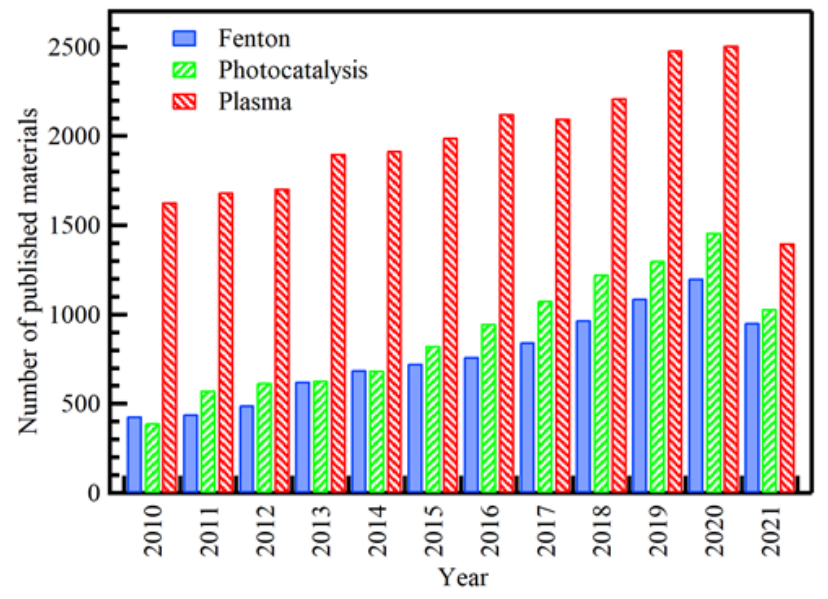

\section{Abstract}

This review provides a general overview of the application of chemical oxidation to hydrophobic contaminants in the form of non-aqueous phase liquids (NAPLs). Six types of chemical oxidation processes, three conventional process: activated persulfate, permanganate, and ozonation, along with three advanced oxidation processes (AOPs):Fenton process, photocatalysis, and plasma oxidation are presented discussed. In addition, this paper provides a brief insight into the combination of chemical oxidation with other remediation technologies for the efficient removal of NAPLs. The common and wide use of activated persulfate for soil remediation is hindered by the fact that it needs heat activation, whereas the main drawback of using permanganate is the precipitation of manganese oxide at the NAPLs face. In addition, the high cost of equipment at the site restricts the ozone application for in-suit soil remediation. The application of AOPs processes such as Fenton and plasma oxidation has received great attention due to its high removal efficiency. However, photocatalysis technology in the field is difficult because it needs photo energy to run the oxidation process. Although plasma oxidation can degrade contaminants in minutes, some active species have short-lived time that could disappear before entering the soil layer. Ozonation is efficient in treat soils with low moisture and large pore spaces. Nevertheless, the optimal $\mathrm{pH}$ for ozonation oxidation is 3 , which is hard to achieve in real-world applications. Combining chemical oxidation with other remediation technology, especially biological remediation, is a valuable technique of soil remediation as the synergetic effects may increase the sustainability of the applied process towards green technology for soil remediation.

Keywords: Advance oxidation process, fenton oxidation, plasma oxidation, NAPLs, soil remediation, combined remediation process.

\section{Introduction}

Soil and groundwater contamination by petroleum hydrocarbon products is a global common problem separate immiscible phase in the subsurface referred to as light non-aqueous phase liquids (NAPLs) (Mateas et al., 2017). Behaviour of NAPL-derived organic pollutants in aquifer systems mainly depends on dissolution of the contaminants within the source zone, the mass transfer to the flowing groundwater, advection, dispersion, diffusion, sorption (retardation) and biodegradation (Aminnaji et al., 2020). The contamination of groundwater by NALPs is a challenging environmental problem that poses risks to 
both human and the environment (Tsai et al., 2008); thus, soil and groundwater remediation, to achieve environmental sustainability and protect human health, has become the shared vision of various stakeholders, including governments, world organizations, and the public (Honetschlägerová et al., 2019). Numerous remediation technologies have been employed to remove NAPLs from soil and groundwater during the last few decades. The mechanism of these technologies can be broadly classified as physical, often due to accidental releases, such as spills during product transportation and storage tanks and pipelines leakage (Cheng et al., 2016). Most petroleum hydrocarbons are lighter than water. Because of their low solubility, they are often present and act as a chemical, and biological whereas and depending on the site of treatment, it is divided as in-situ and ex-situ remediation (Liu et al., 2020a).

The chemical oxidation process aims to be defined as an oxidizer (oxidant) ability to mineralize the organic compounds to carbon dioxide, inorganic, and water or transform harmful ones into harmless or biodegradable compounds (McKenzie et al., 2016). In the last 20 years, In-Suite Chemical Oxidation (ISCO) has become a promising technology for soil and groundwater remediation where the site is contaminated by NAPLS (Ranc et al., 2016). The advantages of chemical oxidation for NAPLs can be summarized as high ability to oxidize NAPLs, relatively an affected by pollutant characteristics and concentration, rapid degradation/destruction of contaminants (measurable result in a short time), competitive cost relative to intensive pump-and-treat systems, non-destructive ( no need to disturbing aboveground structure), and can be used in combination with other remediation technology (Tsai et al., 2008; Mdlovu et al., 2019; Martínez-Pascual et al., 2015).

Hydrogen peroxide $\left(\mathrm{H}_{2} \mathrm{O}_{2}\right)$ was the first oxidant used in full-scale ISCO. Shortly after that, potassium or sodium permanganate $\left(\mathrm{KMnO}_{4}, \mathrm{NaMnO}_{4}\right)$ and ozonation were used to oxidize full-scale remediation (Liu, 2017). Recently, persulphate has become another alternative for soil and groundwater remediation by ISCO (Bennedsen, 2014). The redox potentials $\left(E_{0}\right)$ for this oxidant are: persulfate $(2.01 \mathrm{~V})$, permanganate $(1.70 \mathrm{~V})$, hydrogen peroxide $(1.80 \mathrm{~V})$, and ozone (2.10 V) (Liu, 2017). The hydrogen peroxide solution has been used widely because it dissociates into many strong oxidants to destroy many contaminants quickly. In addition, in the presence of catalyst ions in soil (such as ferrous ions), the production of hydroxyl radicals, which are considered powerful oxidants $(2.86 \mathrm{~V})$, can be accelerated as a Fenton reagent reaction can take place (Kim and Lee, 2012).

The use of permanganate in ISCO is fully developed, and its application in soil and groundwater remediation is well documented as it has been used in numerous sites (Baciocchi, 2013). The main advantages of using permanganate as an oxidant for ISCO are the stability of the oxidant which means it can stay in the subsurface for months and has good distribution due to both diffusive and advective transport. Furthermore, its distinctive purple color makes it notable visually, allowing measuring quantitatively (Anvarov et al., 2019). On the other hand, one of the main drawbacks of using permanganate is the precipitation of manganese dioxide $\left(\mathrm{MnO}_{2}\right)$ at the NAPLs interface and injection wells, respectively, in addition, permanganate alone is an ineffective NAPLs oxidant because of its inability to oxidize benzene rings (Heiderscheidt et al., 2008). Persulfate has been used in ISCO application as it produces sulfate radical, which is considered a strong oxidant where the most known activators of persulfate are heated, chelated iron, and iron (Ko et al., 2012; Wang et al., 2017; Solano et al., 2017; Yang et al., 2020). Sodium persulfate $\left(\mathrm{Na}_{2} \mathrm{~S}_{2} \mathrm{O}_{8}\right)$ is widely used as persulfate salts, while the use of potassium persulfate $\left(\mathrm{K}_{2} \mathrm{~S}_{2} \mathrm{O}_{8}\right)$ is limiting its application as a remediation agent due to its low solubility (Cavanagh et al., 2017; Jousse et al., 2017). As heat can readily activate sulfate radicals, chemical oxidation by persulfate is feasible remediation technology for soil and groundwater pollutants under thermal conditions. However, overuse of persulfate on groundwater remediation, especially those used for drinking purposes, can cause human health problems such as diarrhea (Bennedsen, 2014; Tsai et al., 2008). Finally, chemical oxidation by ozone is advantageous compared to other oxidation processes, such as permanganate, persulfate, and hydrogen peroxide, due to its highest redox potential compared to others. Two ways to apply ozone for soil and groundwater remediation are ozone gas injection in the vadose zone and sparging the ozone gas under the water table (Rivas, 2006). Nevertheless, ozone application in ISCO can be hindered by the capital equipment cost at the site and the limited ozone stability. Degradation of NAPLs may occur either through direct oxidation with ozone or indirectly by hydroxyl radical, which can be generated by ozone's reaction with hydrogen peroxide (Bennedsen, 2014).

In the past few decades, some reviews regarding applying different technologies for NAPLs remediation were documented in the literature. Mulligan et al. (2001) evaluated the effectiveness of three types of biosurfactants on the remediation of contaminated soil in laboratory scale, field, and full-scale applications. They concluded that removing the metals with the anionic biosurfactants even though the exchangeable fractions were not significant. Rivas (2006) reviewed and compared the efficiency of ozone, hydrogen peroxide, and hightemperature pressurized water for Polycyclic aromatic hydrocarbons removal from soil and groundwater. Besha et al. (2018) reviewed the recent advances in surfactant enhanced ISCO to remediation NAPLs in contaminated soils. They focused on three important components of surfactant ISCO includes surfactant/co-solvent mixtures, the catalyst and/or the oxidant, and the free radicals.

The main objective of this review is to evaluate the recent research and development regarding the application of ISCO by both conventional chemical oxidation methods and advanced chemical oxidation. The focus is primarily on the advance oxidation process (AOPs): Fenton, photocatalysis and plasma oxidation. Moreover, the 
results from recent studies are discussed and summarized. This review also comprehensively discusses the the implementation of chemical oxidation in combination with other remediation technology for effective soil and groundwater remediation. Finally, a recommendation for the research needs regarding using chemical oxidation in NAPLs remediation is presented.

\section{The advanced chemical oxidation process}

AOPs is a process of generation of the highly reactive hydroxyl radical ( $\mathrm{OH}$ ) (Flotron et al., 2005; Kang et al., 2006). Different chemical processes can generate $\mathrm{OH}$ such as the Fenton process, photocatalysis, plasma oxidation, UV with ozone, and hydrogen peroxide. The process verity allows competing with the complicity of many treatment systems (Burbano et al., 2005; Venny et al., 2012; Matta et al., 2008; Watts et al., 2002; Yap et al., 2011).

The interest in AOPs started around 1995 and has continued to focus on numerous studies dealing with contaminants and pollutants in the environment (Wang et al., 2009; Quiroga et al., 2009; Zepp et al., 1992). Figure 1 presents the number of publications about AOPs from 2010 to 2020 using AOPs as a searched keyword. The photocatalysis oxidation process for soil remediation is at the top, with around 22038 research in the last 10 years, followed by plasma oxidation with 10386 research articles. The Fenton process for soil remediation is at the top, with around 8280 research in the last 10 years. The following sections describe the key processes involved in these oxidation technologies. Overall, all methods have great attention, and many works are published recently.

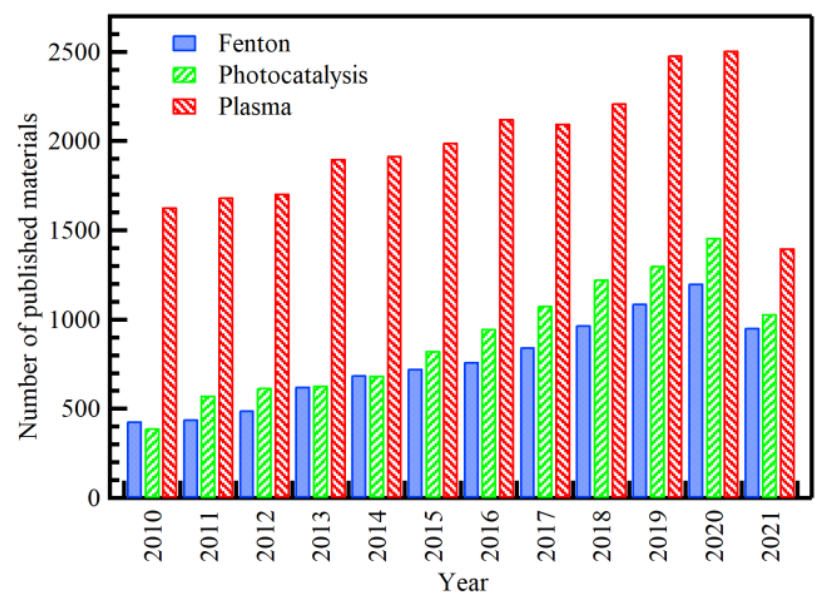

Figure 1. Numbers of articles published from 2010 to 2021 apply advanced oxidation technologies for soil remediation (Scopus, October 2021).

\subsection{Fenton process}

Fenton oxidation involves the generation of hydroxyl radicals by the combination of hydrogen peroxide $\left(\mathrm{H}_{2} \mathrm{O}_{2}\right)$ with soluble catalyst (ferrous ion (Fe(II) or ferric ion (Fe(III)) (Haber and Weiss, 1934). The produced hydroxyl radical is considered among the strongest oxidant $\left(E_{0}=2.73 \mathrm{~V}\right)$, which can oxidize a large list of organic compounds (Flotron et al., 2005; Kang et al., 2006). As seen in Equation 1, the $\mathrm{H}_{2} \mathrm{O}_{2}$ decomposition under the Fenton reaction can produce $\mathrm{OH}$ (Haber and Weiss, 1934). RH and R in Equations 2 and 3 (Flotron et al., 2005; Kang et al., 2006).represent the organic compounds that can be oxidized by $\mathrm{OH}$ using hydrogen abstraction ( $\mathrm{R}^{\prime}$ ) Equation 2 or hydroxyl addition ( $\mathrm{ROH}$ ) in Equation 3. In addition, the formed ferric ions from Equation 1 (Haber and Weiss, 1934) can catalyze $\mathrm{H}_{2} \mathrm{O}_{2}$, as seen in Equation 4 (Haber and Weiss, 1934); this reaction is known as a Fenton-like reaction.

$$
\begin{aligned}
& \mathrm{Fe}^{2+}+\mathrm{H}_{2} \mathrm{O}_{2} \rightarrow \mathrm{Fe}^{3+}+\mathrm{HO}^{-}+\mathrm{OH} \\
& \mathrm{RH}+\mathrm{OH} \rightarrow \mathrm{H}_{2} \mathrm{O}_{2}+\mathrm{R}+\text { further oxidation } \\
& \mathrm{R}+\mathrm{OH} \rightarrow \mathrm{ROH}+\text { further oxidation } \\
& \mathrm{Fe}^{3+}+\mathrm{H}_{2} \mathrm{O}_{2} \leftrightarrow \mathrm{Fe}^{2+}+\mathrm{H}^{+-}+\mathrm{HO}_{2}
\end{aligned}
$$

Fenton/Fenton-like reactions can proceed at atmospheric pressure and room temperature but are highly $\mathrm{pH}$ dependent due to the iron ions (Fe(II) and Fe(III) and the speciation factors of the $\mathrm{H}_{2} \mathrm{O}_{2}$ whereas they (Burbano et al., 2005). The Fenton reaction can be carried out effectively at $\mathrm{pH}$ around 3; a significant reduction in the efficiency can occur with both a small increase or decrease in the $\mathrm{pH}$ value (Venny et al., 2012; Matta et al., 2008). For example, when $\mathrm{pH}$ is below 3 , oxonium ions $\left(\mathrm{H}_{3} \mathrm{O}_{2}{ }^{+}\right)$can be formed when $\mathrm{H}_{2} \mathrm{O}_{2}$ solvate protons. Oxonium ions may enhance the stability of $\mathrm{H}_{2} \mathrm{O}_{2}$, thus, reduce the reactivity of $\mathrm{H}_{2} \mathrm{O}_{2}$ with ferrous ions. For $\mathrm{pH}$ higher than 3, the colloidal ferric species appear as the dissolved fraction of iron ions decrease (Watts et al., 2002).

To deal with this shortcoming, modifications have been proposed for the Fenton reaction to increasing the $\mathrm{pH}$ range. These modifications involve amendments to increase the applicability of the Fenton process in native soil to neutral conditions. Chelators, including nitrilotriacetic acid, cyclodextrin, ethylenediamine tetra acid, and catechol, have been particularly used as modified Fenton reagents. The chelating agents are able to dissolve $\mathrm{Fe}^{3+}$ precipitation by forming complexes (Yap et al., 2011; Rivas, 2006).

Studies have shown that ultraviolet-visible (UV-Vis) light irradiation can facilitate the degradation of organic contamination by Fenton reaction at wavelength values higher than $300 \mathrm{~nm}$ (Wang et al., 2009; Quiroga et al., 2009). In this case, $\mathrm{Fe}^{2+}$ is generated by the photolysis of $\mathrm{Fe}^{3+}$ in the presence of $\mathrm{H}_{2} \mathrm{O}_{2}$ (Zepp et al., 1992). These two reactions are known as the photo-Fenton (Equations 5 and 6) (Burbano et al., 2005). Moreover, $\mathrm{OH}$ also is formatted in photo-Fenton reaction (Equation 7) (Pignatello, 1992; Khataee et al., 2015). However, the photo-Fenton reaction is highly $\mathrm{pH}$-dependent. The optimum $\mathrm{pH}$ value for the photo-Fenton reaction is 2.8 , with $50 \%$ of the $\mathrm{Fe}(\mathrm{III})$ present as $\mathrm{Fe}^{3+}$ and $50 \%$ as $\mathrm{Fe}(\mathrm{OH})_{2}$ (Pignatello, 1992; Khataee et al., 2015). When the $\mathrm{pH}$ is lower than 2.8, the concentration of $\mathrm{Fe}(\mathrm{OH})_{2}{ }^{+}$will decrease, whereas at $\mathrm{pH}$ greater than 2.8 , precipitated 
Fe(III) as oxyhydroxides are observed (Khataee et al., 2015; Kavitha and Palanivelu, 2004).

$$
\begin{aligned}
& \mathrm{Fe}^{2+}+\mathrm{H}_{2} \mathrm{O}_{2} \rightarrow \mathrm{Fe}(\mathrm{OH})^{2+}+\mathrm{OH} \\
& \mathrm{Fe}(\mathrm{OH})^{2+}+h v \rightarrow \mathrm{Fe}^{2+}+\mathrm{OH} \\
& \mathrm{H}_{2} \mathrm{O}_{2}+h v \rightarrow 2 \cdot \mathrm{OH}
\end{aligned}
$$

Another type of Fenton reaction is Electro-Fenton which has attracted more interest in remediation of contaminated soil remediation (Rodrigo et al., 2014; Sirés et al., 2014). The electro-Fenton process can be applied by passing a direct current across transplanted electrodes in the contaminated soil, as shown in Figure 2 and Equation 8(Mousset et al., 2016).

$$
\mathrm{M}+\mathrm{H}_{2} \mathrm{O} \rightarrow \mathrm{M}(\cdot \mathrm{OH})+\mathrm{H}^{+}+e^{-}
$$

In contrast to the general Fenton process, $\mathrm{H}_{2} \mathrm{O}_{2}$ is produced in situ at the cathode as $\mathrm{O}_{2}$ or air pumping near the cathode electrode, whereas the $\mathrm{OH}$ is generated on the anode electrode (Mousset et al., 2016). As the ${ }^{\circ} \mathrm{OH}$ is generated at the bulk, the contamination is destroyed by the Fenton reaction (Mousset et al., 2014b).

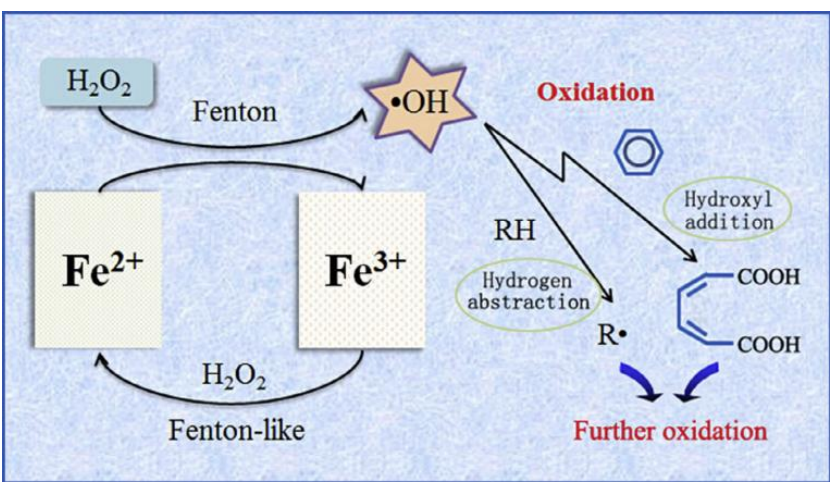

Figure 2. Decomposition of organic compounds by Fenton process (Cheng et al., 2016).

In the Electron-Fenton process, no sludge is generated; thus, this process is considered a green technology for soil remediation as no harmful product is generated (Mousset et al., 2014a, Martínez-Huitle and Brillas, 2009). Moreover, when soil composition has iron ions, no iron addition is needed. Therefore, in certain circumstances, the modified Fenton process is preferred over the traditional Fenton treatment. In addition, in some cases, the modified Fenton process can enhance the contaminant's solubility, increasing the Fenton oxidation efficiency by lowering the interfacial tension (Nam et al., 2001).

\subsection{Photocatalysis}

During the last 40 years, the photocatalysis process for oxidation has been studied extensively (Chen and Mao, 2007; $\mathrm{Yu}$ and $\mathrm{Yu}, 2008)$. In this process, a metalsemiconductor such as Zinc oxide ( $\mathrm{ZnO})$, Tungsten trioxide $\left(\mathrm{WO}_{3}\right)$, Cadmium sulfide (CdS), Nickel oxide (Nio), Gallium phosphide ( $\mathrm{GaP})$, and Titanium dioxide $\left(\mathrm{TiO}_{2}\right)$ is used $(\mathrm{Yu}$ and Yu, 2008; Iwasaki et al., 2000; Chen et al., 2012). Due to its characteristics, $\mathrm{TiO}_{2}$ in the anatase form has been proven as the most suitable semiconductor as it has high photoactivity, low coast, chemical inertness, easy to produce, and non-toxic. On the other hand, $\mathrm{ZnO}, \mathrm{GaP}$, and CdS can dissolve and produce toxic by-products when used in environmental remediation during the photocatalysis process (Chen et al., 2012).

A research involved the preparation of a thin $\mathrm{TiO}_{2}$ film of photonic structure by a sol-gel technique, using PS spheres as a template, with alternating air and $\mathrm{TiO}_{2}$ spaces with a periodicity of approximately $150 \mathrm{~nm}$. The band gap of anatase $\mathrm{TiO}_{2}$ is $3.2 \mathrm{eV}$ and so a photonic band gap in the mid-to-high UV wavelength range (280-380 nm) was required to increase the quantum efficiency of the photocatalyst. (Nakata and Fujishima, 2012; Fujishima et al., 2008). Many investigations on various substrates have well established removing organic contaminants in soils using $\mathrm{TiO}_{2}$ combined with solar light or UV-irradiation (Ochiai and Fujishima, 2012; Kumar and Devi, 2011).

When suitable scavengers ( $\mathrm{HO}^{-}$and/or $\mathrm{H}_{2} \mathrm{O}$ ) are available, $\mathrm{OH}$ can be formed from oxidation reactions as shown in Equations 9 and 10 (Hoffmann et al., 1995). Superoxide radical anion $\left(\mathrm{O}_{2}^{-}\right)$is another reactive radical that can be formed during the photocatalytic process in Equation 11 (Linsebigler et al., 1995; Giahi et al., 2019; Sharifi et al., 2019; Ethiraj et al., 2020). In addition, $\mathrm{O}_{2}^{-}$can lead to the formation of $\mathrm{OH}$ according to Equations 12, 13, and 14 (Ognier et al., 2014). In addition, some adsorbed pollutants may react directly with e- through reductive processes, as shown in Equation 15 (Fox and Dulay, 1993). Figure 3 represents the mechanism of contaminant removal by $\mathrm{TiO}_{2}$ photocatalysis.

$$
\begin{aligned}
& \mathrm{TiO}_{2}\left(h^{+}\right)+\mathrm{H}_{2} \mathrm{O} \rightarrow \mathrm{TiO}_{2}+\mathrm{H}^{+}+\mathrm{OH} \\
& \mathrm{TiO}_{2}\left(h^{+}\right)+\mathrm{HO}^{-} \rightarrow \mathrm{TiO}_{2}+\mathrm{OH} \\
& \mathrm{O}_{2}+e^{-} \rightarrow \mathrm{O}_{2}^{-} \\
& \mathrm{O}_{2}^{-}+\mathrm{H}^{+} \rightarrow \mathrm{HO}_{2} \\
& \mathrm{HO}_{2}+\mathrm{H}^{+}+\mathrm{TiO}_{2}\left(e^{-}\right) \rightarrow+\mathrm{TiO}_{2} \\
& \mathrm{H}_{2} \mathrm{O}_{2}+\mathrm{TiO}_{2}\left(e^{-}\right) \rightarrow \mathrm{OH}+\mathrm{HO}^{-}+\mathrm{TiO}_{2} \\
& \mathrm{RH}+h^{+} \rightarrow \mathrm{H}^{+}+\mathrm{R}
\end{aligned}
$$

UV light irradiation is required to activate the photoreaction with conventional $\mathrm{TiO}_{2}$, a bandgap of 3.2 eV. However, since less than $6 \%$ of the light reaching the Earth is UV light (Pelaez et al., 2012), the photoreaction using sunlight as an energy source may hinder the entire process due to low UV light (Ethiraj et al., 2020; Solehudin et al., 2020; Laouini et al., 2021). Therefore, significant efforts have been directed towards increasing the energy efficiency of photocatalysis reactions. As a result, the photo-response region range of $\mathrm{TiO}_{2}$ has been successfully increased in many studies to reach visible light. This process can be accomplished by introducing additional 
components into the lattice structure (Zhang et al., 2015; Sacco et al., 2015). Metal (e.g., $\mathrm{Fe}, \mathrm{Cr}, \mathrm{V}, \mathrm{Co}$ ) doping and non-metal (e,g., S, C, F, N) doping has been investigated in this domain. Both have successfully extended the visible light response of the $\mathrm{TiO}_{2}$ to photocatalyst reaction (Sacco et al., 2015; Iwasaki et al., 2000).

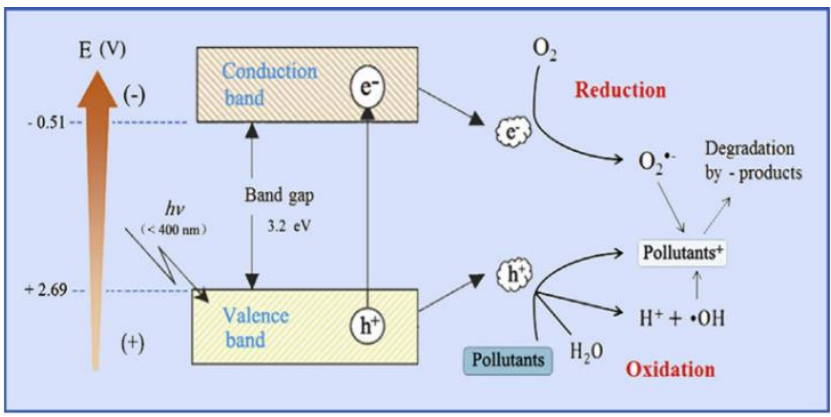

Figure 3. Decomposition of organic compounds by photocatalysis process(Cheng et al., 2016).

\subsection{Plasma oxidation}

Plasma oxidation is considered a competitive technology for organic pollutants removal from soil. Recently, plasma oxidation was investigated as an eco-innovative technology for soil remediation. Low-temperature plasma (LTPs) techniques have received great attention for soil remediation due to the following advantages (1) rapid start and low energy consumption; (2) long service life of equipment; (3) wide application range and high purification efficiency; and (4) lack of additional additives and secondary pollution (Zhao et al., 2019). LTPs methods such as dielectric barrier discharge (DBD) (Ognier et al., 2014; Aggelopoulos et al., 2015) and pulsed corona discharge (PCD) (Wang et al., 2014a) are most investigated. When plasma production occurs, electrons with high energy are produced, affording highly reactive species and space charge. Highly reactive species include $\cdot \mathrm{OH}, \mathrm{O}$ and $\mathrm{H}$ radicals, and ozone, $\mathrm{H}_{2} \mathrm{O}_{2}$ molecules (Lou et al., 2012; Wang et al., 2015; Wang et al., 2014b).

\section{Conventional chemical oxidation process for NAPL remediation}

\subsection{Permanganate}

Table 1 presents the overview of the previous work carried out in the remediation of NAPLs by conventional chemical oxidation methods. Some of these studies are discussed below.

Soil and groundwater remediation with permanganate involves injecting permanganate in the form of sodium or potassium permanganate $\left(\mathrm{NaMnO}_{4}\right.$ or $\left.\mathrm{KMnO}_{4}\right)$ in the contaminated site to degrade the pollutant such as NAPLs (Zhang et al., 2020). In a recent study, Bajagain et al. (2019) studied potassium permanganate with bioaugmentation foam for diesel contaminated soil for the first time. Results showed that combining two methods achieved up to $92.1 \%$ removal efficiency of diesel from the initial concentration of $5542 \mathrm{mg} / \mathrm{kg}$ ). These methods separately achieved $37 \%$ removal efficiency for the potassium permanganate and $72.1 \%$ for bioaugmentation foam. In an earlier study, Matta and
Chiron (2017) examined the performance of permanganate for the oxidation of pentachlorophenol in contaminated soil. The results showed that permanganate has a good ability to oxidize pentachlorophenol. The removal efficiency reached around $77 \%$ after $24 \mathrm{~h}$, demonstrating the ability of permanganate as an ISCO reagent.

\subsection{Activated persulfate}

Recently, activated persulfate has been used for soil and ground remediation due to its high redox potential $(E=2.01 \mathrm{~V})$. Persulfate can be activated by ferrous ions or heat to generate sulfate free radicals $\left(\mathrm{SO}_{4}^{--}\right)$, which is considered a strong oxidizer. Many studies used activate persulfate to degrade contaminants such as petroleum hydrocarbons and chlorinated organic compounds. Chang et al. (2018) investigated the efficiency of activated persulfate for remediation of Trichloroethene (TCE). Results showed $100 \%$ TCE removal from the first site and around $95 \%$ in the second site. The result indicated that one injection of $275 \mathrm{Kg}$ of $5 \%$ persulfate was better than two injections in sequence with $137.5 \mathrm{~kg}$.

In another study, Li et al. (2017) studied the effect of alkalinity, chloride, and $\mathrm{pH}$ on benzene degradation from contaminated groundwater. The results showed that an increase of $\mathrm{pH}$ accelerated persulfate decomposition because of the formation of reactive surface hydroxy complexation at high $\mathrm{pH}$, whereas the increase of the alkalinity decreases the rate of persulfate decomposition, consequently, the degradation of benzene. The change in chloride concentration in the groundwater sample had no significant effect on the decomposition of persulfate nor benzene degradation. In a recent study, Liu et al. (2020b) studied the performance of biochar activated persulfate on the degradation of bisphenol in contaminated soil. For soil spiked with $31.93 \mathrm{mg} \mathrm{kg}^{-1}$ bisphenol, the result pointed out that biochar can effectively activate persulfate to produce activated persulfate and hydroxyl radicals to remove bisphenol from contaminated soil.

\subsection{Ozone Treatment}

Soil remediation by $\mathrm{O}_{3}$ is considered one of the most promising technologies among the technologies that can be applied "on-site" or "in situ". Two methods of $\mathrm{O}_{3}$ an applied; the first one uses $\mathrm{O}_{3}$ as an oxidation agent for contaminant decomposition (direct method), whereas the second one uses $\mathrm{O}_{3}$ to generate $\mathrm{OH}$, which can oxidize the organic contaminants better than $\mathrm{O}_{3}$ itself (Andaluri and Suri, 2017). Forming $\mathrm{OH}$ by ozone decomposition at $\mathrm{pH}$ greater than 6 is formulated to follow the indirect reaction pathway. In soil remediation, many studies have demonstrated the feasibility of using $\mathrm{O}_{3}$ to degrade pesticides, PCBs, hydrocarbons, and polycyclic aromatic hydrocarbons (PAHs) in soil (Andreozzi, 1999; Yu et al., 2007; Pierpoint et al., 2003).

Tamadoni and Qaderi (2019) investigated the removal of phenanthrene, anthracene, and benz(a)anthracene from contaminated soil by ozonation. They found that the removal efficiency of anthracene, phenanthrene, and benz(a)anthracene were 67.87, 85.2, and 45.9\%, 
respectively. Remarkably, the results showed that better removal of PAHs contaminants from soil and groundwater is achieved when the fine-grained soil particle fraction is less and for higher aqueous phase solubility.

Table 1. Recent studies applied conventional chemical oxidation methods for NAPLs remediation

\begin{tabular}{|c|c|c|c|c|}
\hline Technology & Contaminate & Experimental Condition & Important results & References \\
\hline $\begin{array}{l}\text { Activation of } \\
\text { persulfate with } \\
\text { biochar }\end{array}$ & Bisphenol & $\begin{array}{l}\mathrm{pH} 7 \\
\text { Biochar dose }(0.25-2.0) 1 \mathrm{~g} \mathrm{~L}^{-1} \\
\text { Persulfate concentration }(2-15 \mathrm{mM})\end{array}$ & $\begin{array}{l}\text { Increasing persulfate and biochar dosage increased } \\
\text { the degradation of bisphenol where the higher } \\
\text { dosage of persulfate or biochar may decrease } \\
\text { bisphenol removal due to the consumption of } \\
\text { hydroxyl radicals and sulfate radicals in the spiked } \\
\text { soil remediation, } \\
\text { The acidification of the soil due to the drop of pH } \\
\text { can be mitigated by adding biochar. }\end{array}$ & $\begin{array}{l}\text { (Liu et al., } \\
\text { 2020b) }\end{array}$ \\
\hline Ozonation & $\begin{array}{l}\text { Phenanthrene, } \\
\text { anthracene, } \\
\text { benz(a)anthracene }\end{array}$ & $\begin{array}{l}\text { Ozone concentration }(0.1-5.5 \mathrm{~g} / \mathrm{h}) \\
\text { Contaminants concentrations }(7.5 \mathrm{mg} / \mathrm{kg} \text { and } \\
517.5)\end{array}$ & $\begin{array}{l}\text { The Removal efficiency of phenanthrene was } \\
67.87 \% \text {, where the removal efficiency of } \\
\text { anthracene and benz(a)anthracene was } 85.2 \% \text { and } \\
45.9 \% \text {, respectively } \\
\text { For ozonation remediation: less fine-grained soil } \\
\text { and high-water solubility cantonment are the } \\
\text { results in high remediation }\end{array}$ & $\begin{array}{l}\text { (Tamadoni } \\
\text { and Qaderi, } \\
\text { 2019) }\end{array}$ \\
\hline $\begin{array}{c}\text { Potassium } \\
\text { permanganate }\end{array}$ & Pentachlorophenol & $\begin{array}{l}\mathrm{pH} 7 \\
\text { pentachlorophenol initial concentration } 50 \mathrm{mg} \\
\mathrm{L}^{-1} \\
\text { concentration of } \mathrm{KMnO}_{4}=5.6 \mathrm{mM} \\
\text { Experiment time } 24 \mathrm{~h} \\
\text { temperature range of } 20-22^{\circ} \mathrm{C}\end{array}$ & $\begin{array}{l}\text { Permanganate oxidation has a high potential for in } \\
\text { situ renditions of aromatic organochlorine such as } \\
\text { pentachlorophenol. }\end{array}$ & $\begin{array}{l}\text { (Tamadoni } \\
\text { and Qaderi, } \\
\text { 2019) }\end{array}$ \\
\hline $\begin{array}{l}\text { Activated } \\
\text { persulfate }\end{array}$ & Trichloroethene & $\begin{array}{l}\text { TCE initial concentration }(0.26 \text { and } 0.361) \mathrm{mg} \\
\mathrm{L}^{-1} \text { in the first and second per hole, respectively. }\end{array}$ & $\begin{array}{l}\text { The removal efficiency of } 100 \% \text { in the first per } \\
\text { hole and } 95 \% \text { in the second per hole } \\
\text { One injection of } 275 \mathrm{~kg} \text { of } 5 \% \text { persulfate was } \\
\text { better than two injections of } 137.5 \mathrm{~kg} \text { in TCE } \\
\text { removal. } \\
\text { Persulfate is still active for } 14 \text { days in the aquifer }\end{array}$ & $\begin{array}{l}\text { (Chang et al., } \\
\text { 2018) }\end{array}$ \\
\hline $\begin{array}{l}\text { Activated } \\
\text { Persulfate }\end{array}$ & Benzene & $\begin{array}{l}\text { Initial concentration } 1 \mathrm{mM} \text { benzene } \\
\text { Chloride concentrations }(0-5) \mathrm{mM} \\
\text { pH was adjusted between } 8 \text { and } 13 \text {. }\end{array}$ & $\begin{array}{l}\text { Higher } \mathrm{pH} \text { enhances remediation throughout the } \\
\text { formation of hydroxo complexes, whereas higher } \\
\text { alkalinity decreases the persulfate activity by } \\
\text { forming an unreactive surface carbonate complex. } \\
\text { No effect of Chloride on the persulfate } \\
\text { decomposition }\end{array}$ & $\begin{array}{l}\text { (Li et al., } \\
\text { 2017) }\end{array}$ \\
\hline $\begin{array}{l}\text { Permanganate with } \\
\text { bioaugmentation. }\end{array}$ & $\begin{array}{l}\text { Petroleum } \\
\text { hydrocarbons }\end{array}$ & $\begin{array}{l}\text { TPH concentration }(5542 \mathrm{mg} / \mathrm{kg}) \text {. } \\
\text { Permanganate dosage }(0.5 \text {-pore-volume }) \text {. } \\
\text { Treatment time } 1 \text { month. }\end{array}$ & $\begin{array}{l}\text { TPH removal efficiency was around } 92 \% \text { through } \\
\text { permanganate and bioaugmentation, while } 72 \% \\
\text { removal efficiency was achieved by permanganate } \\
\text { alone. }\end{array}$ & $\begin{array}{l}\text { (Chowdhury } \\
\text { et al., 2017) }\end{array}$ \\
\hline $\begin{array}{l}\text { Electrokinetic- } \\
\text { enhanced } \\
\text { permanganate (EK- } \\
\text { PM) }\end{array}$ & Trichloroethene & $\begin{array}{l}\text { Permanganate concentration } 30 \mathrm{~g} / \mathrm{L} \\
25 \mathrm{~mA} \text { direct current }(\mathrm{DC}) \\
\text { Experiment time } 50 \mathrm{~h} \\
\text { Initial concentration } 771 \mathrm{mg} / \mathrm{L}\end{array}$ & $\begin{array}{l}\text { EK-PM system enhanced the delver of } \\
\text { permanganate to dense strata layer, which } \\
\text { increases the removal efficiency of TCE. }\end{array}$ & $\begin{array}{l}\text { (Chowdhury } \\
\text { et al., 2017) }\end{array}$ \\
\hline $\begin{array}{l}\text { Ozone and } \\
\text { peroxide }\end{array}$ & 1,4-dioxane & $\begin{array}{l}\text { Ozone dosage }(1-20) \mathrm{mg} \mathrm{L}^{-1} \\
\text { Peroxide dosage }(1,5 \text {, and } 10) \mathrm{mg} \mathrm{L}^{-1} \\
\text { Initial concentration of } 1,4 \text {-dioxane } 100 \mathrm{mg} \mathrm{L}^{-1}\end{array}$ & $\begin{array}{l}\text { Low removal efficiency at an acidic condition } \\
\text { where high removal efficiency was observed at pH } \\
\text { between } 8 \text { and } 10 \\
\text { Mass transfer of ozone into water is gas flow rate } \\
\text { dependent. Therefore, to increase the mass transfer } \\
\text { of ozone, the gas flow rate should be increased }\end{array}$ & $\begin{array}{l}\text { (Andaluri and } \\
\text { Suri, 2017) }\end{array}$ \\
\hline
\end{tabular}

\section{Advance chemical oxidation process for NAPL remediation}

\subsection{Fenton process}

Table 2 summarizes the previous works conducted in the remediation of NAPLs by the Fenton process. Among the AOP process, the Fenton process is considered the most popular one in the remediation of NAPLs. Farzadkia et al. (2014) studied the effect of the Fenton process to remove total petroleum hydrocarbons (TPH) from oily sludge. Results revealed that at the operating condition: reaction time $1 \mathrm{~h}, \mathrm{H}_{2} \mathrm{O}_{2}$ to $\mathrm{Fe}(\mathrm{II})$ molar ratio of $10, \mathrm{H}_{2} \mathrm{O}_{2}$ to sample mass ratio of 15 , and $\mathrm{pH}$ of 5 , the removal efficiency of TPH was $36.5 \%$. Xu et al. (2018) used a stepwise oxidation process to remove adsorbed THM on soil. After 3 steps of adding $\mathrm{H}_{2} \mathrm{O}_{2}$ the total TPH removal efficiency was $49.6 \%$, with around $20 \%$ increase compared to adding $\mathrm{H}_{2} \mathrm{O}_{2}$ initially in conventional Fenton oxidation. In another study, Qin et al. (2019) conducted batch experiments to investigate the effect of the ferrous ion source in the degradation of long-chain petroleum hydrocarbon from the soil. The results showed that the decomposition rate of petroleum hydrocarbons, ferrous sulfate, and magnetite was the same at $\mathrm{H}_{2} \mathrm{O}_{2}$ dose of $1.5 \%$, whereas the ability of pyrite to start Fenton like reaction was weaker than ferrous sulfate and magnetite. In another study, Chok et al. (2020) investigated the removal of two TPH from the groundwater by Fenton oxidation. The study reported that the Fenton process could remove more than $47 \%$ of $\mathrm{COD}$ at the operation condition; $\mathrm{H}_{2} \mathrm{O}_{2}(0.1 \mathrm{~g} / \mathrm{L}), \mathrm{Fe}$ $(0.01 \mathrm{~g} / \mathrm{L}), \mathrm{pH} 6$, and reaction time of 120 minutes. Santos et al. (2018) used four soil samples to investigate the effect of soil physicochemical properties on gasoline contaminated soil treated by Fenton oxidation process. The results showed that soil samples, such as Red Argisol, Red-Yellow Argisol, and Red Latosol, with high iron content, were more remediable because ion minerals content enable the Fenton process.

Rodríguez et al. (2018) used three approaches in the same reactor (microfluidic cells, anodic oxidation with diamond anodes, and an electro-Fenton process). The authors reported that using those systems in the same reactor can increase the removal efficiency of clopyralid from the soil compared to the conventional treatment technologies in 
terms of high treatment efficiency and short treatment time. In another study, Roohi and Fatehifar (2019) investigated the removal of tert-butyl mercaptan from contaminated soil using bimetallic Fenton treatment that included $\mathrm{Fe}^{2+} / \mathrm{Fe}^{3+} / \mathrm{Fe}^{0} / \mathrm{Cu}^{2+}$ in the presence of gasoline. They found that to reach approximately full removal of tertbutyl mercaptan, the optimum conditions should be: initial gasoline concentration $(2.5 \% \mathrm{w} / \mathrm{w}), \mathrm{CUSO}_{4}(0.12 \%$ $\mathrm{w} / \mathrm{w}), \mathrm{H}_{2} \mathrm{O}_{2}(8.92 \% \mathrm{w} / \mathrm{v})$, nano-ZVI $(0.1194 \% \mathrm{w} / \mathrm{w})$ and nano- $\mathrm{Fe}_{3} \mathrm{O}_{4}(0.899 \% \mathrm{w} / \mathrm{w})$. Sun et al. (2021) investigated the removal efficiency of 2,3,4,5-tetrachlorobiphenyl from contaminated soil using the heterogenous Fenton process. A high removal rate was obtained (76.3\%) after $80 \mathrm{~min}$ of reaction at operating condition of montmorillonite supported nanoscale zero-valent iron $29.88 \mathrm{~g} \mathrm{~kg}^{-1}, \mathrm{H}_{2} \mathrm{O}_{2}$
$45.99 \mathrm{~g} \mathrm{~kg}^{-1}$ and initial $\mathrm{pH}$ 3.5. Zhang et al. (2015) investigated the efficiency of three-electrode electroFenton for groundwater remediation where Rhodamine B was used as a contaminant. Introducing the third electrode increased the $\mathrm{H}_{2} \mathrm{O}_{2}$ formation to reach around $20.9 \mathrm{ml} \mathrm{L}^{-1}$, yielding a removal efficiency of $97.4 \%$. They conclude that the obtained result is higher than the two-electrode E-Fenton systems without aeration by $5 \%$. Another modified Fenton process was developed by Huang et al. (2020) by the reaction between using glucose oxidase and glucose in combination with $\mathrm{Fe}(\mathrm{II})$ (GMFs) to in-situ $\mathrm{H}_{2} \mathrm{O}_{2}$ generation (Figure 4). The developed process was applied to remove TCE from groundwater. Within $8 \mathrm{~h}$, the removal efficiency of TCE reached around $78 \%$.

Table 2. Recent studies using the Fenton process for NAPLs remediation

\begin{tabular}{|c|c|c|c|c|}
\hline Technology & Contaminate & Experimental Condition & Main results & References \\
\hline $\begin{array}{l}\text { Heterogenous Fenton } \\
\text { process }\end{array}$ & $\begin{array}{l}2,3^{\prime}, 4,5- \\
\text { tetrachlorobiphenyl } \\
\text { (PCB67) }\end{array}$ & $\begin{array}{l}\text { Montmorillonite supported nanoscale zero- } \\
\text { valent iron concentration } 29.88 \mathrm{~g} \mathrm{~kg}^{-1} \text {. } \\
\mathrm{H}_{2} \mathrm{O}_{2} \text { concentration } 45.99 \mathrm{~g} \mathrm{~kg}^{-1} \text {. } \\
\text { pH } 3.5 \\
\text { Treatment time } 80 \text { minutes. }\end{array}$ & $\begin{array}{l}\text { High removal efficiency }(76.38 \%) \text { of } 2,3^{\prime}, 4,5- \\
\text { tetrachlorobiphenyl at the investigated condition }\end{array}$ & $\begin{array}{l}\text { (Sun et al., } \\
2021 \text { ) }\end{array}$ \\
\hline Fenton oxidation & $\begin{array}{l}\text { Total petroleum } \\
\text { hydrocarbon (TPH) }\end{array}$ & $\begin{array}{l}\mathrm{H}_{2} \mathrm{O}_{2} \text { concentration }(0.01-0.1) \mathrm{mg} \mathrm{L}^{-1} \\
\mathrm{pH} \text { range (3-6), } \\
\mathrm{Fe}(\mathrm{II}) \text { concentration }(0.01-0.5) \mathrm{mg} \mathrm{L}^{-1} \\
\text { Fenton oxidation reaction time }(30-120) \\
\text { minutes. }\end{array}$ & COD removal from $5.61 \%$ to $47.16 \%$. & $\begin{array}{l}\text { (Chok et al., } \\
\text { 2020) }\end{array}$ \\
\hline $\begin{array}{l}\text { Glucose oxidase } \\
\text { modified Fenton } \\
\text { reactions (GMF) }\end{array}$ & $\begin{array}{l}\text { Trichloroethene } \\
\text { (TCE) }\end{array}$ & $\begin{array}{l}\text { Modified Fenton system was formed by the } \\
\text { combination of } \mathrm{Fe}(\mathrm{II}) \text { and the reaction } \\
\text { between glucose oxidase and glucose. }\end{array}$ & $\begin{array}{l}\text { The removal efficiency of TCE was } 78 \% \text { within } 8 \\
\text { h. }\end{array}$ & $\begin{array}{l}\text { (Huang et } \\
\text { al., 2020) }\end{array}$ \\
\hline Fenton process & $\begin{array}{l}\text { Total petroleum } \\
\text { hydrocarbons (TPH) }\end{array}$ & $\begin{array}{l}\text { Reaction time } 1 \mathrm{~h} \text {. } \\
\mathrm{H}_{2} \mathrm{O}_{2} \text { mass ratio } 15 \% \text {. } \\
\text { pH } 5 \\
\text { Molar ratio of } \mathrm{H}_{2} \mathrm{O}_{2} \text { to } \mathrm{Fe}(\mathrm{II}) \text { was } 10 \% \text {. }\end{array}$ & $\begin{array}{l}\text { The low removal efficiency }(36.47 \%) \text { of TPH was } \\
\text { attributed to the semi-solid nature of the sample } \\
\text { where the hydroxyl radicals were produced in the } \\
\text { aqueous solution. Thus, adding water to the } \\
\text { sample enhanced the removal efficiency of TPH. }\end{array}$ & $\begin{array}{l}\text { (Santos et } \\
\text { al., 2018) }\end{array}$ \\
\hline Fenton-like processes & $\begin{array}{l}\text { long-chain petroleum } \\
\text { hydrocarbons }\end{array}$ & $\mathrm{H}_{2} \mathrm{O}_{2}$ dosage $(1.5 \%)$ & $\begin{array}{l}\text { The removal efficiency of the aliphatic C } 35-\mathrm{C} 40 \text {, } \\
\mathrm{C} 21-\mathrm{C} 35 \text {, and } \mathrm{C} 16-\mathrm{C} 21 \text { was } 25 \%, 50 \% \text {, and } 70 \% \text {, } \\
\text { respectively. } \\
\text { The decomposition rate of petroleum } \\
\text { hydrocarbons ferrous sulfate and magnetite was } \\
\text { the same at an } \mathrm{H}_{2} \mathrm{O}_{2} \text { dose of } 1.5 \% \text {, whereas the } \\
\text { ability of pyrite to start Fenton like reaction was } \\
\text { weaker than ferrous sulfate and magnetite }\end{array}$ & $\begin{array}{l}\text { (Qin et al., } \\
\text { 2019) }\end{array}$ \\
\hline $\begin{array}{l}\text { Microfluidic cells } \\
\text { coupled with diamond } \\
\text { anodes and electro- } \\
\text { Fenton process. }\end{array}$ & Clopyralid & $\begin{array}{l}\mathrm{pH} 3 \\
\text { Initial concentration of clopyralid } 100 \mathrm{mg} \mathrm{kg}^{-1}\end{array}$ & $\begin{array}{l}\text { High treatment efficiency in a short time rivaling } \\
\text { that the investigating coupled system is a } \\
\text { promising technology for soil remediation, }\end{array}$ & $\begin{array}{l}\text { (Rodríguez } \\
\text { et al., 2018) }\end{array}$ \\
\hline $\begin{array}{l}\text { Electro-Fenton (E- } \\
\text { Fenton) }\end{array}$ & Rhodamine B & $\begin{array}{l}\text { Current at }(-1,-3 \text { and }-5) \mathrm{mA} \text {. } \\
\text { The rhodamine initial concentration }\left(5 \mathrm{mg} \mathrm{L}^{-1}\right) \\
\text { Fe(II) ion concentration }(0.5 \mathrm{mM}) \text {. } \\
\text { Reaction time } 120 \text { minutes. }\end{array}$ & High removal efficiency of rhodamine $(97.4 \%)$ & $\begin{array}{l}\text { (Zhang et al., } \\
\text { 2017) }\end{array}$ \\
\hline
\end{tabular}

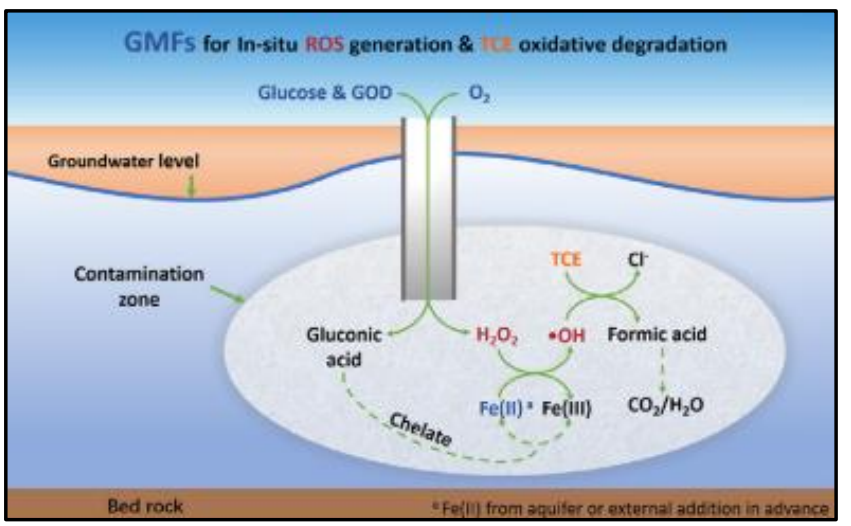

Figure 4. Glucose in combination with Fe(II) (GMFs) remediation technology (Huang et al., 2020).

\subsection{Photocatalysis}

In a recent study, Satyro et al. (2016) studied the performance of $\mathrm{TiO}_{2}^{-}$photocatalytic treatment of soil washing effluent. Different artificial sunlight was used to remove $\mathrm{Fe}, \mathrm{Zn}, \mathrm{Cu}$, and ethylenediamine succinic acid (EDDS). The results showed that, for effluent produced from the soil washing process, $\mathrm{TiO}_{2}$ based photocatalytic process could remove both heavy metals and organic chelate simultaneously. In addition, using artificial solar light on the photocatalytic process can be efficient. In another study, Wang et al. (2016a) investigated the photocatalytic oxidation pathway of diphenylarsinic acid (DPAA) contaminated soil by nano-sized titanium dioxide $\left(\mathrm{TiO}_{2}\right)$. They found that soil: water ratio has a greater effect on DPAA removal efficiency than other characteristics. Gunti et al. (2015) pointed out that UV and visible radiation can remediate organic compounds 
(methyl orange and naphthalene) when combined with graphed doped $\mathrm{TiO}_{2}$ nanostructured photocatalytic materials. Another attempt has been presented by Hsu et al. (2019), who synthesized $\mathrm{LaFeO}_{3}$ by sol-gel method and studied the removal of Trichlorethylene (TCE) from groundwater by $\mathrm{LaFeO}_{3}$ photocatalytic oxidation. A 95\% removal efficiency of TCE was achieved in an aqueous solution where the operating parameters were $\mathrm{LaFeO}_{3}$ concentration of $2 \mathrm{~g} \mathrm{~L}^{-1}$ and $1 \mathrm{~h}$ Xenon lamp illumination.

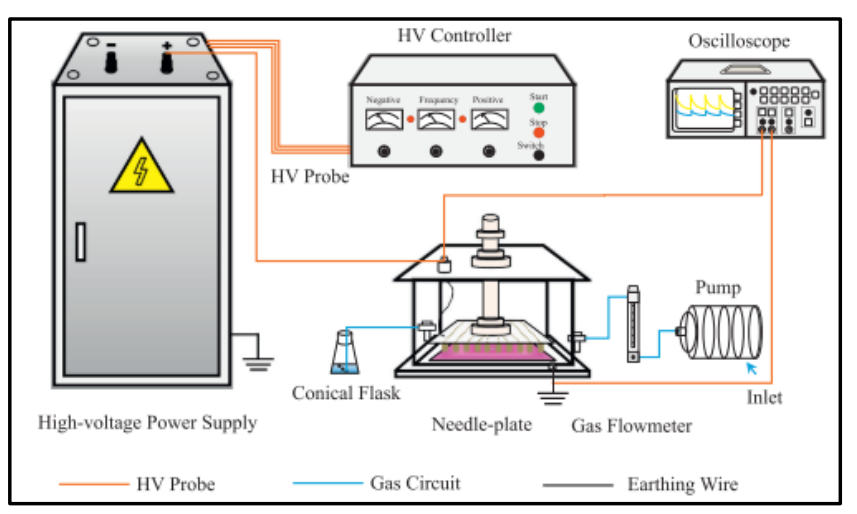

Figure 5. PCD reactor for soil remediation (Zhan et al., 2019).

\subsection{Plasma oxidation}

Redolfi et al. (2010) was the first researcher who used LTP discharges to treat contaminated soil. The kerosene oxidation in the soil matrix was investigated by using a DBD reactor at atmospheric pressure. Results showed that the kerosine removal efficacy reached $90 \%$ in the soil matrix. In another study, Mu et al. (2016) investigated the influence of treatment time, electrode gap initial contaminated concentration, discharge voltage, gas flow rate, and $\mathrm{pH}$ of the soil on the performance of a DBD plasma reactor. The result indicated that the soil $\mathrm{pH}$ has a small effect on the removal efficiency of pyrene, whereas the increase of the applied voltage and decrease of electrode gap enhances the removal efficiency. In another study, Wang et al. (2015) examined the effect of gas vasculitis, species scavengers, and airflow rate on $\mathrm{H}_{2} \mathrm{O}_{2}$ formation during the use of a multi-channel pulsed discharge plasma for removal of p-nitrophenol from contaminated soil. The results showed that the formation rate of $\mathrm{H}_{2} \mathrm{O}_{2}$ in $\mathrm{O}_{2}$ plasma atmosphere was higher than $\mathrm{Ar}$, $\mathrm{N}_{2}$, and air atmospheres. In addition, hydroxyl radical's formation was obtained in the $\mathrm{O}_{2}$ atmosphere case. Zhan et al. (2019) used a PCD reactor (Figure 5) to degrade gasoline from soil and fix nitrogen. The results indicated that removal rate was affected by input power, gas flow rate, electrode gap, soil moisture, $\mathrm{pH}$, and initial gasoline concentration. They found that PCD technology was able to remediate gasoline contaminated soil and improve soil nitrogen content and physical characteristics simultaneously.

In another study, Wang et al. (2016c) explored the feasibility of using atmospheric pressure DBD to remediation glyphosate-contaminated soil. It was reported that around $93 \%$ removal efficiency of polyphosphoric was removed from contaminant soil after $45 \mathrm{~min}$ with an energy yield of $0.47 \mathrm{~g} \mathrm{KW} \mathrm{L}^{-1}$. Table 3 summarizes some representative studies focused on plasma oxidation. Lu et al. (2016) studied the degradation of PAHs contaminated soil using a pulsed corona discharge plasma system. The results showed that under optimum conditions (treatment time $40 \mathrm{~min}$, voltage 18 $\mathrm{kV}$, airflow rate $0.8 \mathrm{~L} / \mathrm{min}$, and frequency $70 \mathrm{~Hz}$ ) the removal efficiency was around $70 \%$; this result suggests pulsed corona discharge plasma was a potential method for remediation of PAH-contaminated soil. Furthermore, it was reported that pyrene removal was higher at neutral $\mathrm{pH}$, whereas $\mathrm{p}$-nitrophenol was more degradable at basic soil.

\section{Combined chemical oxidation with other mitigation methods for NAPL remediation}

Synergetic studies can be characterized as: combination with soil flushing, a combination with biotreatment, and a combination of much chemical oxidation at the same time. Recently, a combination of chemical oxidation with other mitigation methods has received more attention. In this section, an over the review of the recent works in this domain is presented.

Several studies combined chemical oxidation and soil washing; Huguenot et al. (2015) proposed a new system to enhance the remediation of hydrocarbon contamination from soil. They use soil washing followed by Electro-Fenton oxidation. First, an ex-situ soil column washing experiment was conducted using Tween 80 as a washing solution. Then, the collected leached from the bottom of the column was treated by Electro-Fenton technology. The result showed that complete mineralization (more than 99\%) of the hydrocarbons was observed after $32 \mathrm{~h}$ treatment by Electro-Fenton oxidation. In a subsequent study, Seo et al. (2015) studied the combination of an enhanced electrokinetic-Fenton process with soil washing to remove TPHs and zinc from polluted soil. The result pointed that the removal of TPHs and zinc enhanced using $10 \% \mathrm{H}_{2} \mathrm{O}_{2}$ in synthetic soil, whereas in a real soil sample, the removal efficacy decreased due to the complexity of real contaminated soil. Subsequently, Popescu et al. (2017) evaluated the combination of electrokinetic technology and the Fenton process for the simultaneous soil flushing and degradation of TPH. It was reported that, after 15 and 27 days, the removal efficiency of TPH reached 54.4 and $58.2 \%$, respectively, for an initial concentration of TPHs of $80.4 \mathrm{~g}$ $\mathrm{kg}^{-1}$.

Another approach has been developed for the combination of chemical oxidation technology and bioremediation. For example, Liu et al. (2020c) developed a combined Electro-Fenton and bioslurry (EF-bioslurry) combined process for remediation of PAHs contaminated soil with an initial concentration of $3605 \mathrm{mg} \mathrm{kg}^{-1}$. After 24 $\mathrm{h}$ treatment by electro-Fenton, the removal efficiency was $92.5 \%$. Remarkably, the removal efficiency increased to $99 \%$ after 40 days of bio-slurry treatment. 
Table 3: Recent studies used plasma oxidation for NAPLs remediation

\begin{tabular}{|c|c|c|c|c|}
\hline Technology & Contaminate & Experimental Condition & Important results & Ref. \\
\hline $\begin{array}{l}\text { Pulse corona discharge } \\
(\mathrm{PCD})\end{array}$ & Gasoline & $\begin{array}{l}\text { Voltage } 0-40 \mathrm{kV} \\
\text { Room temperature around } 25^{\circ} \mathrm{C} \\
\text { pH } 7.2 \\
\text { Gasoline concentration }(2000 \mathrm{mg} / \mathrm{kg})\end{array}$ & $\begin{array}{l}\text { Under the optimal condition, the gasoline removal } \\
\text { efficiency was } 90 \% \text {; simultaneously, the nitrogen } \\
\text { concentration was increased from } 0 \text { to } 14 \mathrm{ppm} \text {. }\end{array}$ & $\begin{array}{l}\text { (Zhan } \\
\text { et al., } \\
2019)\end{array}$ \\
\hline $\begin{array}{ll}\text { Dielectric } & \text { barrier } \\
\text { discharge (DBD) plasma }\end{array}$ & Pyrene & $\begin{array}{l}\text { The initial concentration of pyrene was } 100 \\
\mathrm{mg} \mathrm{kg}^{-1} \\
\text { Peak to peak voltage } 31.6,33.8 \text {, and } 36.2 \mathrm{kV} \\
\text { Reaction time }(10,20,30,40,50 \text { and } 60) \mathrm{min}\end{array}$ & $\begin{array}{l}\text { DBD can remove pyrene over a wide range of } \mathrm{pH} \text {. } \\
\text { The removal efficiency was } 60 \% \text { at } 36.2 \mathrm{kV} \text { peak } \\
\text { to peak voltage and } 60 \mathrm{~min} \text { reaction time. }\end{array}$ & $\begin{array}{l}\text { (Mu } \\
\text { et al., } \\
2016)\end{array}$ \\
\hline $\begin{array}{lr}\text { Atmospheric } & \text { pressure } \\
\text { dielectric } & \text { barrier } \\
\text { discharge (DBD) } & \end{array}$ & Glyphosate & $\begin{array}{l}\text { Airflow rate } 1.5 \mathrm{~L} \mathrm{~min}^{-1} \\
\text { Glyphosate initial concentration } 200 \mathrm{mg} \mathrm{kg}^{-1}\end{array}$ & $\begin{array}{l}\text { Around } 93 \% \text { removal efficiency of } \\
\text { polyphosphoric was removed from contaminant } \\
\text { soil after } 45 \text { min with an energy yield of } 0.47 \mathrm{~g} \\
\mathrm{KW} / \mathrm{L} \\
\text { The degradation efficiency was enhanced by } \\
\text { increasing the discharge voltage. }\end{array}$ & $\begin{array}{l}\text { (Wan } \\
\mathrm{g} \quad \text { et } \\
\text { al., } \\
2016 \mathrm{c} \\
\text { ) }\end{array}$ \\
\hline $\begin{array}{l}\text { Pulsed corona discharge } \\
\text { plasma system. }\end{array}$ & $\begin{array}{l}\text { Polycyclic } \\
\text { aromatic } \\
\text { hydrocarbons } \\
\text { (PAHs)/ } \\
\text { Phenanthrene } \\
\text { (Phe) }\end{array}$ & $\begin{array}{l}\text { Initial concentration } 100 \mathrm{mg} / \mathrm{kg} \\
\text { Pulse frequency } 70 \mathrm{~Hz}, \\
40 \mathrm{~min} \text { of discharge treatment } \\
\text { Airflow rate } 0.8 \mathrm{~L} / \mathrm{min}, \\
\text { Pulse voltage } 18 \mathrm{kV} \\
\text { Pulse frequency } 70 \mathrm{~Hz}\end{array}$ & $\begin{array}{l}\text { The degradation efficiency of Phe approached } \\
\text { approximately } 70 \% \text {. }\end{array}$ & $\begin{array}{l}\text { (Lu et } \\
\text { al., } \\
2016)\end{array}$ \\
\hline $\begin{array}{l}\text { A pulsed discharge } \\
\text { plasma (PDP) }\end{array}$ & $\begin{array}{l}\text { P-microphone } \\
\text { and Pyrene }\end{array}$ & $\begin{array}{l}\text { pyrene initial concentration } 100 \mathrm{mg} \mathrm{kg}^{-1} \\
\text { P-nitrophene initial concentration } 300 \mathrm{mg} \mathrm{kg}^{-} \\
\text {Peak voltage } 16.5 \mathrm{kV} \\
\text { Airflow } 1 \mathrm{~L} \mathrm{~min}^{-1} \\
\text { Pulse frequency } 50 \mathrm{~Hz}\end{array}$ & $\begin{array}{l}\text { removal of pyrene was higher at neutral } \mathrm{pH} \text {, } \\
\text { whereas p-nitrophenol was more degradable at } \\
\text { basic soil } \\
\text { For PDP systems, the most important parameter } \\
\text { was pulse discharge time which significantly } \\
\text { affects the energy utilization efficiency. }\end{array}$ & $\begin{array}{l}\text { (Wan } \\
\text { g et } \\
\text { al., } \\
2016 \mathrm{~b} \\
\text { ) }\end{array}$ \\
\hline $\begin{array}{l}\text { Pulsed corona discharge } \\
\text { plasma }\end{array}$ & $\begin{array}{l}\text { Petroleum } \\
\text { hydrocarbons }\end{array}$ & $\begin{array}{l}\text { Contaminant initial concentration } 5000 \mathrm{mg} \\
\mathrm{kg}^{-1} \\
\text { Peak to peak voltage } 30 \mathrm{kV} \\
\text { Treatment time } 60 \mathrm{~min} \\
\text { Soil moisture } 1.44 \% \\
\text { Pulsed frequency } 50 \mathrm{~Hz} \\
\text { Discharge gap distance } 14 \mathrm{~cm}\end{array}$ & $\begin{array}{l}\text { Around } 76 \% \text { of the petroleum contamination was } \\
\text { removed within } 60 \mathrm{~min} \text { from an initial } \\
\text { concentration of } 5000 \mathrm{mg} \mathrm{kg}^{-1} \text { and with an energy } \\
\text { efficacy of } 0.2 \mathrm{mg} \mathrm{kJ}^{-1} \text {. } \\
\text { Soil with high moisture are favorable to } \\
\text { remediation by pulsed corona discharge plasma. }\end{array}$ & $\begin{array}{l}\text { (Li et } \\
\text { al., } \\
2016)\end{array}$ \\
\hline $\begin{array}{l}\text { A multi-channel pulsed } \\
\text { discharge plasma }\end{array}$ & p-nitrophenol & $\begin{array}{l}\text { Gas atmosphere }\left(\text { air, } \mathrm{O}_{2}, \mathrm{Ar} \text {, and } \mathrm{N}_{2}\right) \text {, } \\
\text { airflow rate }(0,0.4,0.8,1.2)(\mathrm{L} / \mathrm{min})\end{array}$ & $\begin{array}{l}\text { Compare to } \mathrm{N}_{2}, \mathrm{Ar} \text {, and air, the } \mathrm{O}_{2} \text { plasma } \\
\text { atmosphere was more efficient in p-nitrophenol } \\
\text { remediation due to the formation of hydroxyl } \\
\text { radicals and } \mathrm{H}_{2} \mathrm{O}_{2} \text {. }\end{array}$ & $\begin{array}{l}\text { (Wan } \\
\text { g et } \\
\text { al., } \\
2015)\end{array}$ \\
\hline
\end{tabular}

In some cases, more than one chemical oxidation method may use at the same time. For example, Liu et al. (2016) studied the combination of catalyzed $\mathrm{H}_{2} \mathrm{O}_{2}$ and activated persulfate to remediation of ortho-nitro chlorobenzene (o-NCB) contaminated soil. The result indicated that combining both oxidation processes enhanced the degradation of o-NCB in soil compared to using these two methods separately. Cui et al. (2017) investigated a novel approach for combining the oxidation process using permanganate and peroxymonosulfate to remediation trichloroethylene and benzene in simulated groundwater. They found that the removal of benzene was related to the activated peroxymonosulfate, where the intermediates competed with trichloroethylene for permanganate.

\section{Conclusion}

This article presents a review of the late advances on the chemical oxidation technologies for NAPLs contaminated soil remediation. The main findings can be itemized as follows:

- Fenton process has received more attention in the last 10 years due to the following advantages: (1) it can degrade a wide range of contaminants, (2) easy to implement, (3) sub-products are usually harmless or biodegradable. However, the main disadvantages of the conventional Fenton process are the huge amounts of chemicals involved and the requirement to decrease soil $\mathrm{pH}$. In addition, $\mathrm{H}_{2} \mathrm{O}_{2}$ injection is often a challenge because enzymes and iron oxides can decompose it.

- The application of $\mathrm{TiO}_{2}$ photocatalyst was largely examined due to its safety, low cost, and high photocatalytic activity (Giahi et al., 2019). However, the main drawback is that photocatalytic degradation only happens in the upper layer of the soil, whereas the efficiency of this technology decreases as it goes deeper into the soil.

- Although plasma oxidation can degrade contaminants in minutes, some active species have short-lived time that could disappear before entering the soil layer. On the other hand, ozonation is efficient in treating soils with low moisture and large pore spaces. Nevertheless, the optimal pH for ozonation oxidation is 3, which hard to achieve in real sites.

Combine chemical oxidation with other remediation technology seems to be the future of soil remediation as the combination process may increase the sustainability 
of the applied process towards green technology for soil remediation.

\section{Recommendations}

This review provides readers with a general overview of chemical oxidation for the remediation of NAPLs contaminated soil. With a special address to AOPs, especially the Fenton process and plasma oxidation process. The main recommendations is pointed as fellows:

- More work needs to be done on modified and combination processes. For example, chemical oxidation and biological, especially Fenton process and bioremediation, seems effective because it is environmentally friendly and low cost.

- Using more than one chemical oxidation method appears to be promising for quick and efficient soil remediation. However, the conflict between the various oxidant must be taken into consideration.

- Another promising strategy is the development of new modifications to increase $\mathrm{TiO}_{2}$ catalysis using sunlight to increase the photo efficiency of the $\mathrm{TiO}_{2}$ and decrease costs. Future studies can also focus on the chemically modified $\mathrm{TiO}_{2}$ for the visible activated photocatalysis.

- Concerning plasma oxidation, although the recent studies demonstrate the efficiency of plasma oxidation on NAPLs remediation, more work is needed to upscale this technology to the field scale.

\section{Acknowledgment}

The research leading to these results has received funding from the Ministry of Higher Education, Research and Innovation (MoHERI) of the Sultanate of Oman under the Block Funding Program, MoHERI Block Funding Agreement No. MoHERI/BFP/ASU/01/2020.

\section{References}

Aggelopoulos C.A., Svarnas P., Klapa M.I. and Tsakiroglou C.D. (2015), Dielectric barrier discharge plasma used as a means for the remediation of soils contaminated by non-aqueous phase liquids. Chemical Engineering Journal, 270, 428-436.

Aminnaji M., Golfier F., Niasar V.J. and Babaei M. (2020). Interplay of biofilm growth, napl biodegradation and microscale heterogeneity in natural attenuation of aquifers delineated by pore-network modelling. Advances in Water Resources,145.

Andaluri G. and Suri R. (2017), Removal of 1,4-dioxane and volatile organic compounds from groundwater using ozonebased advanced oxidation process. Ozone: Science \& Engineering, 39, 423-434.

Andreozzi R. (1999), Advanced oxidation processes (Aop) for water purification and recovery. Catalysis Today, 53, 51-59.

Anvarov A., Angel A.P., Rando B.F. and Gil J.L. (2019), Remediation of groundwater contamination from an old, non-functional landfill in Hořkovec open cast mine, Czech Republic. Journal of Water Supply: Research And Technology-Aqua, 68, 829-841.
Baciocchi R. (2013), Principles, developments and design criteria of in situ chemical oxidation. Water, Air, \& Soil Pollution, 224.

Bajagain R., Gautam P. and Jeong S.-W. (2019), Degradation of petroleum hydrocarbons in unsaturated soil and effects on subsequent biodegradation by potassium permanganate. Environmental Geochemistry And Health, 1-10.

Bennedsen L.R. (2014), In situ chemical oxidation. Chemistry Of Advanced Environmental Purification Processes Of Water. Elsevier.

Besha A.T., Bekele D.N., Naidu R. and Chadalavada S. (2018), Recent advances in surfactant-enhanced in-situ chemical oxidation for the remediation of non-aqueous phase liquid contaminated soils and aquifers. Environmental Technology \& Innovation, 9, 303-322.

Burbano A.A., Dionysiou D.D., Suidan M.T. and Richardson T.L. (2005), Oxidation kinetics and effect of ph on the degradation of Mtbe with fenton reagent. Water Research, 39, 107-118.

Cavanagh B.A., Wilson S.T., Johnson P.C. and Daniels E.J. (2017), Interface treatment of petroleum hydrocarbon-impacted lower permeability layers by activated sodium persulfate to reduce emissions to groundwater. Groundwater Monitoring \& Remediation, 37, 34-42.

Chang Y.-C., Chen T.-Y., Tsai Y.-P. and Chen K.-F. (2018), Remediation of trichloroethene (Tce)-contaminated groundwater by persulfate oxidation: a field-scale study. Rsc Advances, 8, 2433-2440.

Chen A., Zeng G., Chen G., Hu X., Yan M., Guan S., Shang C., Lu L., Zou Z. and Xie G. (2012), Novel thiourea-modified magnetic ion-imprinted chitosan/ $/ \mathrm{TiO}_{2}$ composite for simultaneous removal of cadmium and 2,4-dichlorophenol. Chemical Engineering Journal, 191, 85-94.

Chen X. and Mao S.S. (2007), Titanium dioxide nanomaterials: synthesis, properties, modifications, and applications. Chemical Reviews, 107, 2891-2959.

Cheng M., Zeng G., Huang D., Lai C., Xu P., Zhang C. and Liu Y. (2016), Hydroxyl radicals based advanced oxidation processes (Aops) for remediation of soils contaminated with organic compounds: a review. Chemical Engineering Journal, 284, 582-598.

Chok J.C., Hamzah Z.B., Ma J. and Ho Y.-C. (2020), Remediation on underground water pollution using fenton oxidation method. lop Conference Series: Materials Science And Engineering, 736, 072013.

Chowdhury A.I.A., Gerhard J.I., Reynolds D., Sleep B.E. and O'carroll D.M. (2017), Electrokinetic-enhanced permanganate delivery and remediation of contaminated low permeability porous media. Water Research, 113, 215222.

Cui J., Zhang L., Xi B., Zhang J. and Mao X. (2017), Chemical oxidation of benzene and trichloroethylene by a combination of peroxymonosulfate and permanganate linked by in-situ generated colloidal/amorphous $\mathrm{Mno}_{2}$. Chemical Engineering Journal, 313, 815-825.

Ethiraj A.S., Uttam P.K.V., Chong K.F. and Ali G.A.M. (2020), Photocatalytic performance of a novel semiconductor nanocatalyst: copper doped nickel oxide for phenol degradation. Materials Chemistry And Physics, 242, 122520.

Farzadkia M., Dehghani M. and Moafian M. (2014), The effects of fenton process on the removal of petroleum hydrocarbons from oily sludge in shiraz oil refinery, Iran. Journal of Environmental Health Science And Engineering, 12. 
Flotron V., Delteil C., Padellec Y. and Camel V. (2005), Removal of sorbed polycyclic aromatic hydrocarbons from soil, sludge and sediment samples using the Fenton's Reagent process. Chemosphere, 59, 1427-1437.

Fox M.A. and Dulay M.T. (1993), Heterogeneous photocatalysis. Chemical Reviews, 93, 341-357.

Fujishima A., Zhang X. and Tryk D. (2008), $\mathrm{Tio}_{2}$ photocatalysis and related surface phenomena. Surface Science Reports, 63, 515-582.

Giahi M., Pathania D., Agarwal S., Ali G.A.M., Chong K.F. and Gupta V.K. (2019), Preparation of Mg-doped $\mathrm{Tio}_{2}$ Nanoparticles for photocatalytic degradation of some organic pollutants. Studia Universitatis Babes-Bolyai, Chemia, 64, 7-18.

Gunti S., Kumar A. and Ram M.K. (2015), Comparative organics remediation properties of nanostructured graphene doped titanium oxide and graphene doped zinc oxide photocatalysts. American Journal Of Analytical Chemistry, 06, 708-717.

Haber F. and Weiss J. (1934), The Catalytic decomposition of hydrogen peroxide by iron salts. Proceedings Of The Royal Society Of London. Series A - Mathematical And Physical Sciences, 147, 332-351.

Heiderscheidt J.L., Siegrist R.L. and Illangasekare T.H. (2008), Intermediate-scale $2 \mathrm{~d}$ experimental investigation of in situ chemical oxidation using potassium permanganate for remediation of complex dnapl source zones. Journal of Contaminant Hydrology, 102, 3-16.

Hoffmann M.R., Martin S.T., Choi W. and Bahnemann D.W. (1995), Environmental applications of semiconductor photocatalysis. Chemical Reviews, 95, 69-96.

Honetschlägerová L., Martinec M. and Škarohlíd R. (2019), Coupling in situ chemical oxidation with bioremediation of chloroethenes: a review. Reviews In Environmental Science And Bio/Technology, 18, 699-714.

Hsu Y.-C., Chang S.-H., Chung W.-C. and Chang M.-B. (2019), Photocatalytic removal of trichloroethylene from water with Lafeo $_{3}$. Environmental Science And Pollution Research, 26, 26276-26285.

Huang Y., Liu H., Liu S., Li C. and Yuan S. (2020), Glucose oxidase modified fenton reactions for in-situ ros generation and potential application in groundwater remediation. Chemosphere, 253, 126648.

Huguenot D., Mousset E., Van Hullebusch E.D. and Oturan M.A. (2015), Combination of surfactant enhanced soil washing and electro-fenton process for the treatment of soils contaminated by petroleum hydrocarbons. Journal of Environmental Management, 153, 40-47.

Iwasaki M., Hara M., Kawada H., Tada H. and Ito S. (2000), Cobalt ion-doped $\mathrm{TiO}_{2}$ photocatalyst response to visible light. Journal Of Colloid And Interface Science, 224, 202-204.

Jousse F., Atteia O., Höhener P. and Cohen G. (2017), ReMOVAL OF NAPL FROM COLUMNS BY OXIDATION, SPARGING, SURFACTANT AND THERMAL TREATMEnt. Chemosphere, 188, 182-189.

Kang N., Hua I. and Rao P.S.C. (2006), Enhanced fenton's destruction of non-aqueous phase perchloroethylene in soil systems. Chemosphere, 63, 1685-1698.

Kavitha V. and Palanivelu K. (2004), The role of ferrous ion in fenton and photo-fenton processes for the degradation of phenol. Chemosphere, 55, 1235-1243.

Khataee A., Salahpour F., Fathinia M., Seyyedi B. and Vahid B. (2015), Iron rich laterite soil with mesoporous structure for heterogeneous fenton-like degradation of an azo dye under
Visible Light. Journal of Industrial And Engineering Chemistry, 26, 129-135.

Kim I. and Lee M. (2012), Pilot scale feasibility study for in-situ chemical oxidation using $\mathrm{H}_{2} \mathrm{O}_{2}$ solution conjugated with biodegradation to remediate a diesel contaminated site. Journal Of Hazardous Materials, 241-242, 173-181.

Ko S., Crimi M., Marvin B.K., Holmes V. and Huling S.G. (2012), Comparative study on oxidative treatments of napl containing chlorinated ethanes and ethenes using hydrogen peroxide and persulfate in soils. Journal Of Environmental Management, 108, 42-48.

Kumar S.G. and Devi L.G. (2011), Review on modified $\mathrm{Tio}_{2}$ photocatalysis under Uv/visible light: selected results and related mechanisms on interfacial charge carrier transfer dynamics. The Journal Of Physical Chemistry A, 115, 1321113241.

Laouini S.E., Bouafia A., Soldatov A.V., Algarni H., Tedjani M.L., Ali G.A.M. and Barhoum A. (2021), Green synthesized of ag/ag2o nanoparticles using aqueous leaves extracts of phoenix dactylifera I. and their Azo dye photodegradation. Membranes, 11, 468.

Li R., Liu Y., Mu R., Cheng W. and Ognier S. (2016), Evaluation of pulsed corona discharge plasma for the treatment of petroleum-contaminated soil. Environmental Science And Pollution Research, 24, 1450-1458.

Li W., Orozco R., Camargos N. and Liu H. (2017), Mechanisms on the impacts of alkalinity, $\mathrm{Ph}$, and chloride on persulfatebased groundwater remediation. Environmental Science \& Technology, 51, 3948-3959.

Linsebigler A.L., Lu G. and Yates J.T. (1995), Photocatalysis on tio surfaces: principles, mechanisms, and selected results. Chemical Reviews, 95, 735-758.

Liu J.-W., Wei K.-H., Xu S.-W., Cui J., Ma J., Xiao X.-L., Xi B.-D. and He X.-S. (2020a), Surfactant-enhanced remediation of oilcontaminated soil and groundwater: a review. Science Of The Total Environment, 756, 144142-144142.

Liu J., Jiang S., Chen D., Dai G., Wei D. and Shu Y. (2020b). Activation of persulfate with biochar for degradation of bisphenol a in soil. Chemical Engineering Journal, 381, 122637.

Liu Z. (2017), Oxidation Of Toluene By Ferrous Activated Persulfate In A Glass Replica Of A Rock Fracture.

Liu Z., Gao Z. and Lu X. (2020c), An integrated approach to remove pahs from highly contaminated soil: electro-fenton process and bioslurry treatment. Water, Air, \& Soil Pollution, 231.

Liu Z., Guo W., Han X., Li X., Zhang K. and Qiao Z. (2016), In situ remediation of ortho-nitrochlorobenzene in soil by dual oxidants (hydrogen peroxide/persulfate). Environmental Science And Pollution Research, 23, 19707-19712.

Lou J., Lu N., Li J., Wang T. and Wu Y. (2012) Remediation of chloramphenicol-contaminated soil by atmospheric pressure dielectric barrier discharge. Chemical Engineering Journal, 180, 99-105.

Lu N., Wang C. and Lou C. (2016). Remediation of pahcontaminated soil by pulsed corona discharge plasma. Journal Of Soils And Sediments, 17, 97-105.

Martínez-Huitle C.A. and Brillas E. (2009), Decontamination of wastewaters containing synthetic organic dyes by electrochemical methods: a general review. Applied Catalysis B: Environmental, 87, 105-145.

Martínez-Pascual E., Grotenhuis T., Solanas A.M. and Viñas M. (2015), Coupling chemical oxidation and biostimulation: effects on the natural attenuation capacity and resilience of 
the native microbial community in alkylbenzene-polluted soil. Journal Of Hazardous Materials, 300, 135-143.

Mateas D.J., Tick G.R. and Carroll K.C. (2017), In situ stabilization of napl contaminant source-zones as a remediation technique to reduce mass discharge and flux to groundwater. Journal Of Contaminant Hydrology, 204, 40-56.

Matta R. and Chiron S. (2017), Oxidative degradation of pentachlorophenol by permanganate for Isco application. Environmental Technology, 39, 651-657.

Matta R., Hanna K., Kone T. and Chiron S. (2008), Oxidation of 2,4,6-trinitrotoluene in the presence of different ironbearing minerals at neutral Ph. Chemical Engineering Journal, 144, 453-458.

Mckenzie E.R., Siegrist R.L., Mccray J.E. and Higgins C.P. (2016), The influence of a non-aqueous phase liquid (napl) and chemical oxidant application on perfluoroalkyl acid (Pfaa) fate and transport. Water Research, 92, 199-207.

Mdlovu N.V., Lin K.S., Chen C.Y., Mavuso F.A., Kunene S.C. and Carrera Espinoza M.J. (2019), In-situ reductive degradation of chlorinated dnapls in contaminated groundwater using polyethyleneimine-modified zero-valent iron nanoparticles. Chemosphere, 224, 816-826.

Mousset E., Frunzo L., Esposito G., Hullebusch E.D.V., Oturan N. and Oturan M.A. (2016), A complete phenol oxidation pathway obtained during electro-fenton treatment and validated by a kinetic model study. Applied Catalysis B: Environmental, 180, 189-198.

Mousset E., Oturan M.A., Van Hullebusch E.D., Guibaud G. and Esposito G. (2014a), Soil washing/flushing treatments of organic pollutants enhanced by cyclodextrins and integrated treatments: state of the art. Critical Reviews In Environmental Science And Technology, 44, 705-795.

Mousset E., Oturan N., Van Hullebusch E.D., Guibaud G., Esposito G. and Oturan M.A. (2014b), Treatment of synthetic soil washing solutions containing phenanthrene and cyclodextrin by electro-oxidation. influence of anode materials on toxicity removal and biodegradability enhancement. Applied Catalysis B: Environmental, 160-161, 666-675.

Mu R., Liu Y., Li R., Xue G. and Ognier S. (2016), Remediation of pyrene-contaminated soil by active species generated from flat-plate dielectric barrier discharge. Chemical Engineering Journal, 296, 356-365.

Mulligan C.N., Yong R.N. and Gibbs B.F. (2001), Surfactantenhanced remediation of contaminated soil: a review. Engineering Geology, 60, 371-380.

Nakata K. and Fujishima A. (2012), Tio 2 photocatalysis: design and applications. Journal of Photochemistry And Photobiology C: Photochemistry Reviews, 13, 169-189.

Nam K., Rodriguez W. and Kukor J.J. (2001), Enhanced degradation of polycyclic aromatic hydrocarbons by biodegradation combined with a modified fenton reaction. Chemosphere, 45, 11-20.

Ochiai T. and Fujishima A. (2012), Photoelectrochemical properties of $\mathrm{TiO}_{2}$ photocatalyst and its applications for environmental purification. Journal Of Photochemistry And Photobiology C: Photochemistry Reviews, 13, 247-262.

Ognier S., Rojo J., Liu Y., Duten X., Cavadias S. and Thannberger L. (2014), Mechanisms of pyrene degradation during soil treatment in a dielectric barrier discharge reactor. Plasma Processes And Polymers, 11, 734-744.

Pelaez M., Nolan N.T., Pillai S.C., Seery M.K., Falaras P., Kontos A.G., Dunlop P.S., Hamilton J.W., Byrne J.A. and O'shea K. (2012), A review on the visible light active titanium dioxide photocatalysts for environmental applications. Applied Catalysis B: Environmental, 125, 331-349.

Pierpoint A.C., Hapeman C.J. and Torrents A. (2003), Ozone treatment of soil contaminated with aniline and trifluralin. Chemosphere, 50, 1025-1034.

Pignatello J.J. (1992), Dark and photoassisted iron (3+)-catalyzed degradation of chlorophenoxy herbicides by hydrogen peroxide. Environmental Science \& Technology, 26, 944-951.

Popescu M., Rosales E., Sandu C., Meijide J., Pazos M., Lazar G. and Sanromán M.A. (2017), Soil flushing and simultaneous degradation of organic pollutants in soils by electrokineticfenton treatment. Process Safety And Environmental Protection, 108, 99-107.

Qin J., Lin C., Almebayedh H. and Albader M. (2019), Decomposition of long-chain petroleum hydrocarbons by fenton-like processes: effects of ferrous iron source, salinity and temperature. Ecotoxicology And Environmental Safety, 169, 764-769.

Quiroga J.M., Riaza A. and Manzano M.A. (2009), Chemical degradation of Pcb in the contaminated soils slurry: direct fenton oxidation and desorption combined with the photofenton process. Journal of Environmental Science And Health, Part A, 44, 1120-1126.

Ranc B., Faure P., Croze V. and Simonnot M. (2016), Selection of oxidant doses for in situ chemical oxidation of soils contaminated by polycyclic aromatic hydrocarbons (Pahs): a review. Journal Of Hazardous Materials, 312, 280-297.

Redolfi M., Makhloufi C., Ognier S. and Cavadias S. (2010), Oxidation of kerosene components in a soil matrix by a dielectric barrier discharge reactor. Process Safety And Environmental Protection, 88, 207-212.

Rivas F. (2006), Polycyclic aromatic hydrocarbons sorbed on soils: a short review of chemical oxidation based treatments. Journal Of Hazardous Materials, 138, 234-251.

Rodrigo M.A., Oturan M.A. and Oturan N. (2014), Electrochemically assisted remediation of pesticides in soils and water: a review. Chemical Reviews, 114, 8720-8745.

Rodríguez M., Muñoz-Morales M., Perez J.F., Saez C., Cañizares P., Barrera-Díaz C.E. and Rodrigo M.A. (2018), Toward the development of efficient electro-fenton reactors for soil washing wastes through microfluidic cells. Industrial \& Engineering Chemistry Research, 57, 10709-10717.

Roohi P. and Fatehifar E. (2019), Fast and environmental-friendly degradation of tert-butyl mercaptan from contaminated soil using bimetallic-modified fenton process. Advances In Environmental Technology, 5, 9-21.

Sacco O., Vaiano V., Han C., Sannino D. and Dionysiou D.D. (2015), Photocatalytic removal of atrazine using N-doped tio 2 supported on phosphors. Applied Catalysis B: Environmental, 164, 462-474.

Santos A., Firak D.S., Emmel A., Siedlecki K., Lopes A. and Peralta-Zamora P. (2018), Evaluation of the fenton process effectiveness in the remediation of soils contaminated by gasoline: effect of soil physicochemical properties. Chemosphere, 207, 154-161.

Satyro S., Race M., Marotta R., Dezotti M., Guida M. and Clarizia L. (2016), Photocatalytic processes assisted by artificial solar light for soil washing effluent treatment. Environmental Science And Pollution Research, 24, 6353-6360.

Seo S.-J., Kim J.-H., Shin J.-W. and Park J.-Y. (2015), Treatment of artificial and real co-contaminated soil by an enhanced electrokinetic-fenton process with a soil flushing method. Water, Air, \& Soil Pollution, 226. 
Sharifi A., Montazerghaem L., Naeimi A., Abhari A.R., Vafaee M., Ali G.A.M. and Sadegh H. (2019), Investigation of photocatalytic behavior of modified Zns:Mn/Mwcnts nanocomposite for organic pollutants effective photodegradation. Journal Of Environmental Management, 247, 624-632.

Sirés I., Brillas E., Oturan M.A., Rodrigo M.A. and Panizza M. (2014), Electrochemical advanced oxidation processes: today and tomorrow. a review. Environmental Science And Pollution Research, 21, 8336-8367.

Solano F.M., Marchesi M., Thomson N.R., Bouchard D. and Aravena R. (2017), Carbon and hydrogen isotope fractionation of benzene, toluene, and O-xylene during chemical oxidation by persulfate. Groundwater Monitoring \& Remediation, 38, 62-72.

Solehudin M., Sirimahachai U., Ali G.A.M., Chong K.F. and Wongnawa S. (2020), One-pot synthesis of isotype heterojunction $\mathrm{G}-\mathrm{C}_{3} \mathrm{n}_{4}-\mathrm{Mu}$ photocatalyst for effective tetracycline hydrochloride antibiotic and reactive orange 16 dye removal. Advanced Powder Technology, 31, 1891-1902.

Sun Y.-M., Feng L. and Yang L. (2021), Degradation of Pcb67 In soil using the heterogenous fenton process induced by montmorillonite supported nanoscale zero-valent iron. Journal Of Hazardous Materials, 406, 124305.

Tamadoni A. and Qaderi F. (2019), Optimization of soil remediation by ozonation for Pahs contaminated soils. Ozone: Science \& Engineering, 41, 454-472.

Tsai T.T., Kao C.M., Yeh T.Y. and Lee M.S. (2008), Chemical oxidation of chlorinated solvents in contaminated groundwater: review. Practice Periodical of Hazardous, Toxic, And Radioactive Waste Management, 12, 116-126.

Venny, Gan S. and Ng H.K. (2012), Inorganic chelated modifiedfenton treatment of polycyclic aromatic hydrocarbon (Pah)contaminated soils. Chemical Engineering Journal, 180, 1-8.

Wang A.N., Teng Y., Hu X.-F., Wu L.-H., Huang Y.-J., Luo Y.-M. and Christie P. (2016a), Diphenylarsinic acid contaminated soil remediation by titanium dioxide (P25) photocatalysis: degradation pathway, optimization of operating parameters and effects of soil properties. Science of The Total Environment, 541, 348-355.

Wang H., Zhou G., Guo H., Ge Z. and Yi C. (2016b), Organic compounds removal in soil in a seven-needle-to-net pulsed discharge plasma system. Journal Of Electrostatics, 80, 6975.

Wang L., Peng L., Xie L., Deng P. and Deng D. (2017), Compatibility of surfactants and thermally activated persulfate for enhanced subsurface remediation. Environmental Science \& Technology, 51, 7055-7064.

Wang T., Qu G., Sun Q., Liang D. and Hu S. (2015), Formation and roles of hydrogen peroxide during soil remediation by direct multi-channel pulsed corona discharge in soil. Separation And Purification Technology, 147, 17-23.

Wang T., Ren J., Qu G., Liang D. and Hu S. (2016c), Glyphosate contaminated soil remediation by atmospheric pressure dielectric barrier discharge plasma and its residual toxicity evaluation. Journal Of Hazardous Materials, 320, 539-546.

Wang T.C., Qu G., Li J. and Liang D. (2014), Evaluation of the potential of soil remediation by direct multi-channel pulsed corona discharge in soil. Journal Of Hazardous Materials, 264, 169-175.

Wang T.C., Qu G., Li J. and Lu N. (2014b), Transport characteristics of gas phase ozone in soil during soil remediation by pulsed discharge plasma. Vacuum, 101, 8691.
Wang Y., Liu C.S., Li F.B., Liu C.P. and Liang J.B. (2009), Photodegradation of polycyclic aromatic hydrocarbon pyrene by iron oxide in solid phase. Journal of Hazardous Materials, 162, 716-723.

Watts R.J., Stanton P.C., Howsawkeng J. and Teel A.L. (2002), Mineralization of a sorbed polycyclic aromatic hydrocarbon in two soils using catalyzed hydrogen peroxide. Water Research, 36, 4283-4292.

Xu J., Yang C., Li L., Huang T. and Huang R. (2018), Enhancing the removal of sorbed crude oil from soil through multiple oxidation steps in stepwise fenton processes. Soil And Sediment Contamination: An International Journal, 27, 369382.

Yang Z.-H., Verpoort F., Dong C.-D., Chen C.-W., Chen S. and Kao C.-M. (2020), Remediation of petroleum-hydrocarbon contaminated groundwater using optimized in situ chemical oxidation system: batch and column studies. Process Safety And Environmental Protection, 138, 18-26.

Yap C.L., Gan S. and Ng H.K. (2011), Fenton based remediation of polycyclic aromatic hydrocarbons-contaminated soils. Chemosphere, 83, 1414-1430.

Yu D.-Y., Kang N., Bae W. and Banks M.K. (2007), Characteristics in oxidative degradation by ozone for saturated hydrocarbons in soil contaminated with diesel fuel. Chemosphere, 66, 799-807.

$\mathrm{Yu}$ J. and $\mathrm{Yu}$ X. (2008), Hydrothermal synthesis and photocatalytic activity of zinc oxide hollow spheres. Environmental Science \& Technology, 42, 4902-4907.

Zepp R.G., Faust B.C. and Hoigne J. (1992), Hydroxyl radical formation in aqueous reactions (Ph 3-8) of iron(li) with hydrogen peroxide: the photo-fenton reaction. Environmental Science \& Technology, 26, 313-319.

Zhan J., Zhang A., Héroux P., Li X., Li Z., Zhao J., Guo Y. and Liu Y. (2019), Gasoline degradation and nitrogen fixation in soil by pulsed corona discharge plasma. Science of The Total Environment, 661, 266-275.

Zhang H., Wan X., Li G. and Zhang F. (2017), A three-electrode electro-fenton system supplied by self-generated oxygen with automatic ph-regulation for groundwater remediation. Electrochimica Acta, 250, 42-48.

Zhang T., Liu Y., Zhong S. and Zhang L. (2020), Aops-based remediation of petroleum hydrocarbons-contaminated soils: efficiency, influencing factors and environmental impacts. Chemosphere, 246, 125726.

Zhang Y., Han C., Nadagouda M.N. and Dionysiou D.D. (2015), The fabrication of innovative single crystal N, F-codoped titanium dioxide nanowires with enhanced photocatalytic activity for degradation of atrazine. Applied Catalysis B: Environmental, 168, 550-558.

Zhao C., Dong Y., Feng Y., Li Y. and Dong Y. (2019), Thermal desorption for remediation of contaminated soil: a review. Chemosphere, 221, 841-855. 